\title{
A study on the painting techniques and materials of the murals in the Five Northern Provinces' Assembly Hall, Ziyang, China
}

Kejia Hu ${ }^{1 *}$, Chongbin Bai ${ }^{2 *}$, Linyan $\mathrm{Ma}^{2}, \mathrm{Ke} \mathrm{Bai}^{2}$, Dongbo Liư ${ }^{2}$ and Binbin Fan ${ }^{2}$

\begin{abstract}
A limited amount of analytical data is available on the techniques and materials used in the murals of the Qing dynasty (1636-1911) in China. The Five Northern Provinces' Assembly Hall (1861-1874) is located in Wafangdian on the confluence of two rivers. It has the largest murals in Shaanxi Province. This paper presents the first comprehensive investigation of the painting techniques and materials of the murals in the Five Northern Provinces Assembly Hall. The analytical methods include polarized light microscopy (PLM), microscopic examination on crosssections, $x$-ray fluorescence (XRF), $x$-ray diffraction (XRD), micro-Raman spectroscopy ( $\mu$-RS), Fourier transform infrared spectroscopy (FTIR) and scanning electron microscopy with an energy-dispersive spectrometer (SEM-EDX), which have been used to examine the paint layer stratigraphy, plaster layers, the priming layer and inorganic pigments composition. The results show that the carrier was firstly prepared with two levels of coarse layers, which are made of clay, sand and rice straw applied onto the brick wall, and a fine coat layer made of lime, clay, sand and cotton follows. Then a kaolin-pigmented priming layer was painted on the fine coat, which was finally painted with red lead, red ochre, cinnabar, atacamite, malachite, botallackite, orpiment, yellow ochre, Prussian blue, smalt, azurite, lead white and flame carbons on top. The research suggests that the painting materials of the murals of the Five Northern Provinces' Assembly Hall are original and the techniques were well implemented and followed the traditional and standard way in ancient China. But a few details present strong local characteristics, such as using rice straw, cotton and kaolin as original materials which were more convenient to obtain. This study also indicates that only one red dyestuff was found, and the other colourants are all inorganic. Except Prussian blue, smalt and botallackite used in ancient mural in China were less reported, and the rest of the pigments represent traditional Chinese painting materials. In addition, the usage of the imported pigments Prussian blue and smalt proves that the geographic position of the Five Northern Provinces' Assembly Hall was of crucial importance for trade.
\end{abstract}

Keywords: The Five Northern Provinces' Assembly Hall, Murals in the Qing dynasty, Painting technique, Pigments identification

\section{Introduction}

The Five Northern Provinces' Assembly Hall is located in Wafangdian, $8 \mathrm{~km}$ west of Ziyang in Shaanxi Province in China. Wafangdian is a small countryside village on the confluence of the Zhu River and Ren River (Figure 1). The Ren River flows into the Hanjiang River, which is the longest tributary of the Yangzi River. They formed the main trade channel from the southeast to southwest.

\footnotetext{
*Correspondence: hukejia13@gmail.com; bcb571@163.com

'School of Cultural Heritage, Northwest University, Xi'an, Shaanxi, P.R. China

${ }^{2}$ Shaanxi Province Institute for the Conservation and Restoration of Cultural Heritage, Xi'an, Shaanxi, P. R. China
}

(c) 2013 Hu et al.; licensee Chemistry Central Ltd. This is an Open Access article distributed under the terms of the Creative Commons Attribution License (http://creativecommons.org/licenses/by/2.0), which permits unrestricted use, distribution, and reproduction in any medium, provided the original work is properly cited.
In the middle of the Qing dynasty, Wafangdian was a small town of crucial importance for its geographical position on the travelling and trade routes. Six assembly halls and five temples were built here since businessmen from different provinces gathered for trade. Nowadays the Five Northern Provinces' Assembly Hall is the only intact building complex which witnessed the commercial prosperity of the Qing dynasty. The stage house and audience house of the assembly hall were constructed at the end of the Qianlong period (about 1790). The name of the assembly hall is attributed to financial aid to drum tower, bell tower, transit hall and main hall with murals 


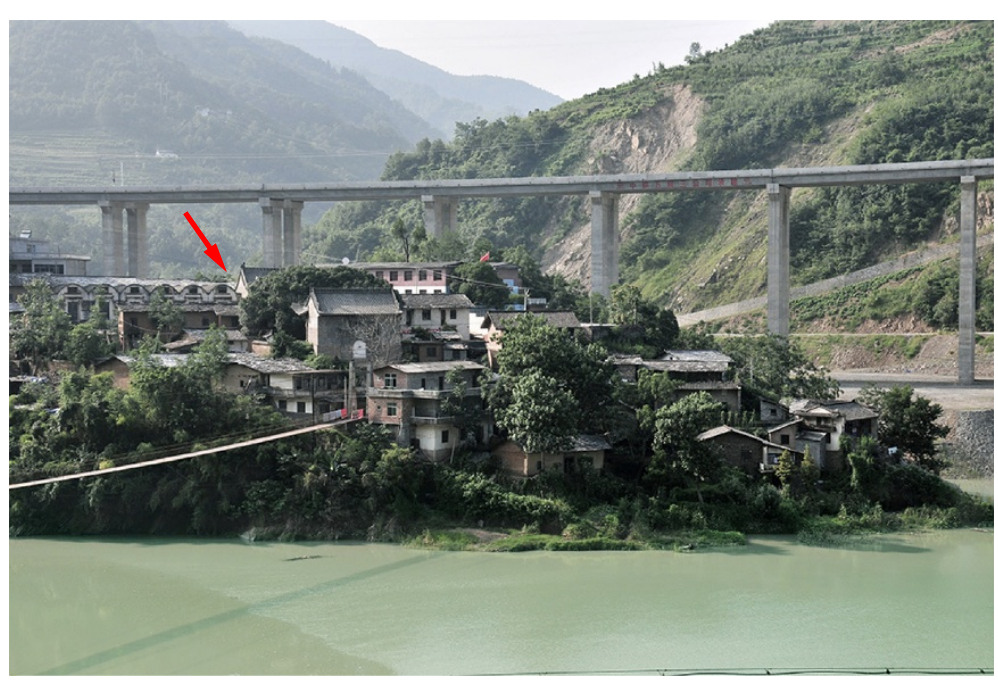

Figure 1 Location of the Five Northern Provinces' Assembly Hall. The Five Northern Provinces' Assembly Hall is located in a small town named Wafangdian on the confluence of the Zhu River and Ren River, 8 km west of Ziyang in Shaanxi Province in China.

in the Tongzhi period (1861-1874) by businessmen from the five provenances, including Shaanxi, Shanxi, Henan, Gansu and Shandong Province. The assembly hall was used as a grain storehouse in 1952. The walls of the transit and main hall have been covered with wooden planks to keep the grain dry until the exquisite murals were discovered during a survey of cultural heritage in 2007. There are nine different wall paintings (Figure 2). The murals on the gable walls were designed as counterparts: In the transit hall, for example, two traditional

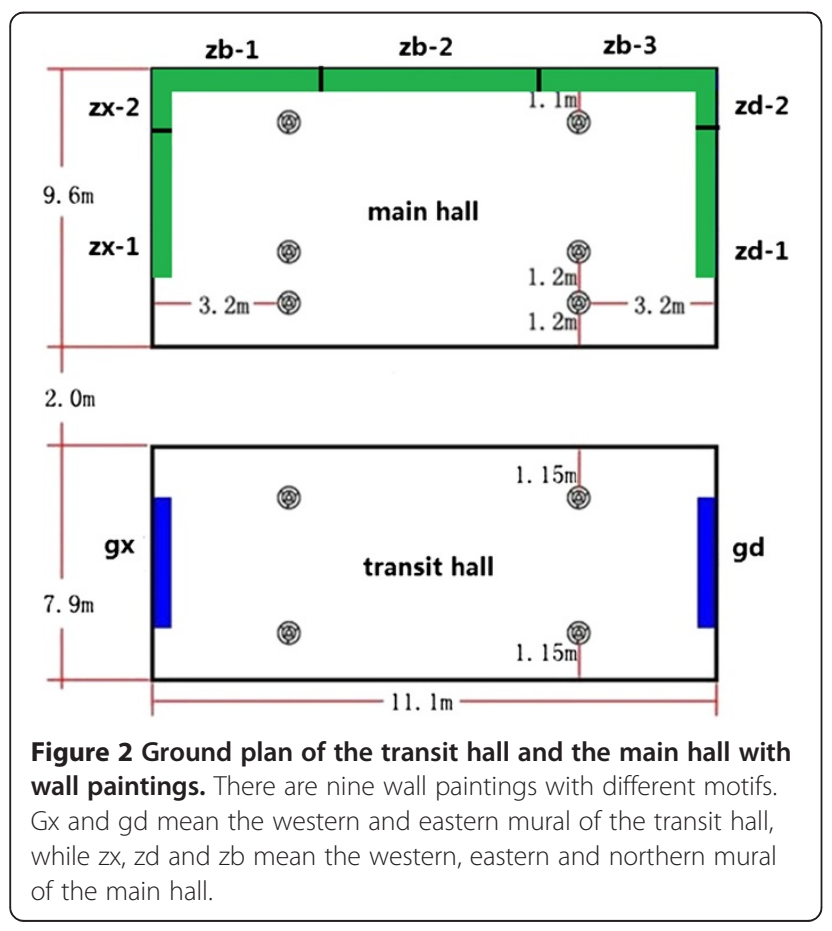

Chinese folding screens were depicted with elaborate painted panels, some of them showing the tales of 24 Exemplars of Filial Piety (Figure 3a, b). The two largest murals located in the main hall, present stories from the novel "Three Kingdoms" (Figure 3c,d). The murals are of high artistic quality.

Research reports on the murals of the Qing dynasty are significantly fewer than for earlier dynasties. Furthermore, an overwhelming amount of related literature is focused on the content or art value [1,2], compared with that, limited analyses of the materials and techniques have been reported. In order to understand the painting techniques and materials, the paint layer samples were examined and analyzed by polarized light microscopy, microscopic examination on cross-sections, $\mathrm{x}$-ray fluorescence, $x$-ray diffraction, micro-Raman spectroscopy, Fourier transform infrared spectroscopy and SEM-EDX. It is the first time that the comprehensive analyses have been carried out on the murals of the Five Northern Provinces' Assembly Hall. Study on the materials is not only useful to understand the technique of folk wall painting in the Qing dynasty, but also crucial for subsequent conservation on the murals.

\section{Experiments}

\section{Samples}

28 samples were taken from different coloured areas of the murals, including red, green, yellow, blue, brown, black and white paint layer, 11 of them come from the transit hall, 17 from the main hall. In addition, 8 plaster samples were extracted individually from western wall of the transit hall, western and northern wall of the main hall, containing two coarse layers and a fine coat. 


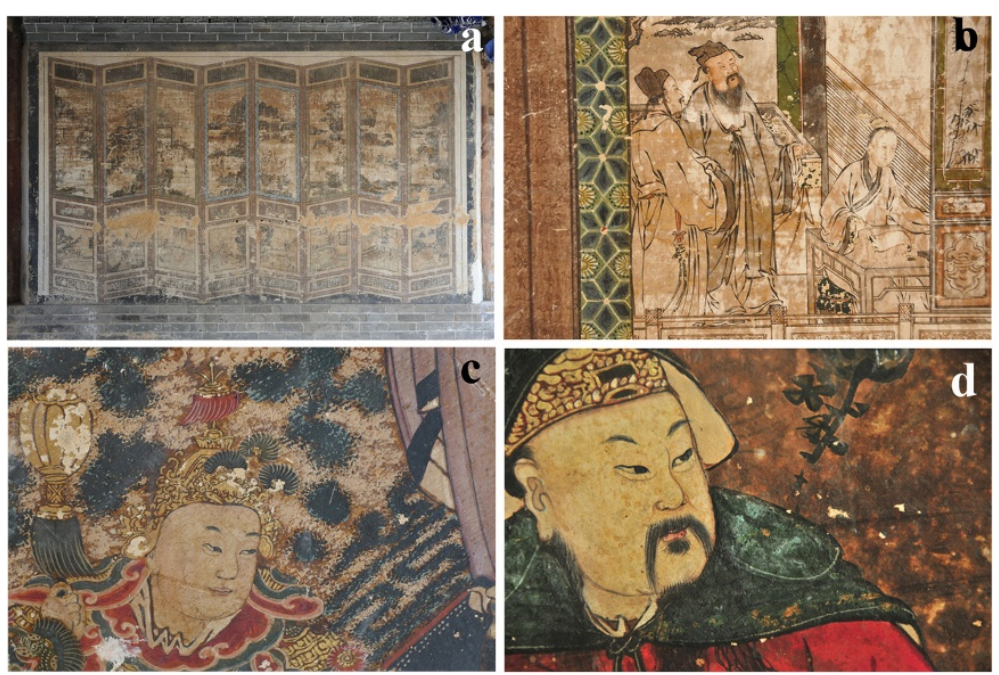

Figure 3 Pictures of the murals in the Five Northern Provinces' Assembly Hall. $\mathbf{a}$ and $\mathbf{b}$ show the mural of the transit hall depicted a traditional Chinese folding screen with elaborate painted panels, some showing the tales of 24 Exemplars of Filial Piety. While $\mathbf{c}$ and $\mathbf{d}$ show the details of the eastern wall painting of the main hall, telling the stories from the novel "Three Kingdoms".

\section{Methodology \\ Optical microscopy}

Samples were embedded in a transparent resin (poly methyl methacrylate), then ground and polished to obtain cross-sections. Subsequent optical observations were carried out with a Japan Hirox $\mathrm{KH}-7700$ digital microscope.

\section{Polarized light microscopy}

A Leica DMLSP polarized light microscope was used for examinations in transmitted and reflected light with a microphotography capability. Powder samples were embedded in Melt Mount with a refractive index of 1.662 and covered with a cover-glass.

\section{$X$-ray fluorescence}

Elemental determination of the samples was carried out by a Bruker ARTAX-400 x-ray fluorescence spectrometer, with the measuring conditions: Molybdenum target, voltage $30 \mathrm{kV}$, current $900 \mu \mathrm{A}$, live time $200 \mathrm{~s}$.

\section{$X$-ray diffraction}

Rigaku D/max-2500 x-ray diffraction with a CuK radiation, $40 \mathrm{kV}$ and $200 \mathrm{~mA}$, graphite monochromator filter was used to characterize the pigment composition. The plaster samples were ground into powder for $\mathrm{x}$-ray diffraction analyses. Diffraction patterns were interpreted by comparison with JCPDS data.

\section{Micro-Raman spectroscopy}

The powder samples were dispersed by anhydrous alcohol before analysis. Analyses were carried out by a Renishaw in Via-Reflex micro-Raman spectrometer comprising a Leica DMLM microscope, with the following conditions: a laser excitation at $514.5 \mathrm{~nm}$; a $50 \times$ microscope objective; $300 \mathrm{~mm}$ slits; integration time 10 s and 5 to 20 accumulations.

\section{Fourier transform infrared spectroscopy (FT-IR)}

FT-IR spectroscopy for the priming layer was measured on a Bruker Tensor 27 Fourier transform infrared spectrometer. The sample was ground into powder and dispersed in $\mathrm{KBr}$ disks. Spectrums were collected from 4000 to $400 \mathrm{~cm}^{-1}$, with a resolution of $4 \mathrm{~cm}^{-1}$ and 64 scans.

\section{SEM-EDX}

Some samples of the wall paintings from the Five Northern Provinces' Assembly Hall consist of several paint layers. It is available to gain elements in every layer by SEM-EDX analysis to get comprehensive information of the materials. SEM images by secondary electron (SE) or back-scattered electrons (BSE) and EDX analyses were taken by a Tescan VEGA 3XM scanning microscope equipped with an energy dispersive $\mathrm{x}$-ray spectrometer. An accelerating voltage of $20 \mathrm{kV}$ was used and a work distance of $15 \mathrm{~mm}$. Except for one gold sample was measured directly with a low voltage of $15 \mathrm{kV}$, other cross-section samples were gold-coated.

\section{Results and discussion Stratigraphy observation}

The northern wall of the main hall has been seriously damaged. A large area of plaster was detached and fell down because of mobility of soluble salt. Three plaster layers were observed at the position of the loss of the mural. The plaster consists from bottom to top of the 
first coarse layer (10-12 $\mathrm{mm})$, the second coarse layer (5-7 $\mathrm{mm})$, and the fine coat $(3-5 \mathrm{~mm})$.

Table 1 shows the results of the microscopic examination on cross-sections. Most of the samples from the Five Northern Provinces' Assembly Hall comprise three parts, the paint layers, the priming layer and the fine coat. The thickness of paint layer varies from 10 to $40 \mu \mathrm{m}$ in general, and few from the main hall (sample $\mathrm{zx}$ $1-6,1-7,1-8)$ are thicker, about $60-100 \mu \mathrm{m}$, while the priming layer varies from 20 to $60 \mu \mathrm{m}$ on average.

\section{Plaster layers}

Two different fabric strips from the mural plaster were investigated by the digital microscope and scanning electronic microscope. The micrographs of the fibre in the coarse layer shows the same characteristics as fresh rice straw, margins of the fabric strip with several transparent spines (Figure 4a,b). Because of aging or mechanical friction during the process of mixing the mortar, the fibre sample has a similar vertical texture on surface without denticulations (Figure 4c,d). So the fibre used in the coarse layers is determined as rice straw. Ziyang belongs to south China where is warm, humid and rich in rice. Therefore, using rice straw as the fibre is convenient. Another kind of fabric strips in the fine coat is flat shaped with natural torsion and its cross-section is irregular waist round and hollow, corresponding to the micro-morphological characteristics of cotton fibres [3].

Figure 5 shows the SEM images of the plaster samples. Compared to the first coarse layer, holes are smaller and the grains on the surface are arranged more intensively in the second coarse one. While fine coat particles' size is relatively uniform. The EDX analysis results are shown in Table 2. The data indicate that elemental contents of the transit hall samples and the main hall samples are similar. The fine coat has a higher content of calcium (about 30\%) than the coarse layers. In addition, there is a thin layer $(3-10 \mu \mathrm{m})$ with a large amount of $\mathrm{Ca}$ (average is as high as $40 \%$ above) was observed on the surface of the fine coat. A simulated experiment was operated to explore the main cause of it. According to recipes of the plaster, two coarse layers and a fine layer were made on four bricks. Then a traditional technique of pressing and sliding on the fine coat surface was performed to make it smooth and compact. 10 times was operated on the fine coat surface of sample 1. While 15 times for Sample 2 and 20 times for sample 3. Moreover, sample 4 is a blank sample. The observation of samples shows that the sample surface is whiter with the increase of the plattening times. The EDX results of these crosssections indicate that the content of $\mathrm{Ca}$ on the surface was significantly higher than fine coat when the times reach 15. It suggests that higher content of $\mathrm{Ca}$ was caused by repeating press and slide with a platten on the plaster surface to make it smooth and compact.

Furthermore, samples of plaster were found to contain quartz $\left(\mathrm{SiO}_{2}\right)$, calcite $\left(\mathrm{CaCO}_{3}\right)$, plagioclase $((\mathrm{Na}, \mathrm{Ca}) \mathrm{Al}(\mathrm{Si}$, $\left.\mathrm{Al})_{3} \mathrm{O}_{8}\right)$ as well as illite $\left(\mathrm{K}_{0.75}\left(\mathrm{Al}_{1.75} \mathrm{R}\right)\left[\mathrm{Si}_{3.5} \mathrm{Al}_{0.5} \mathrm{O}_{10}\right](\mathrm{OH})\right.$ ${ }_{2}$ ) by XRD analysis (Table 3 ). The percentage of quartz in the coarse layer samples reaches above $70 \%$. And the fine coat samples are with lower content of quartz (55\%) and higher calcite $(20 \%)$, which reassured the results of EDX analysis. Moreover, white inclusions in the fine coat layer were identified as calcite, which suggest that the fine coat is made of lime, clay and sand.

\section{The priming layer}

Elemental analyses on the priming layer were carried out on the cross-sections. The priming layers were found to be dominated by $\mathrm{Si}, \mathrm{Al}$ and $\mathrm{O}$, and atomic ratios of $\mathrm{Si}$ and $\mathrm{Al}$ are almost equal, which suggests that the priming layer is made of kaolinite $\left(\mathrm{Al}_{2} \mathrm{Si}_{2} \mathrm{O}_{5}(\mathrm{OH})_{4}\right)$.

Figure 6 illustrated the infrared absorption spectrum of the priming layer of sample zx1-8. The wave number for 3697, 3669 and $3654 \mathrm{~cm}^{-1}$ are kaolinite octahedral coordination external $\mathrm{O}-\mathrm{H}$ absorption peaks. The peak nearby $3620 \mathrm{~cm}^{-1}$ caused by O-H vibration on the interface of kaolinite structure unit layer tetrahedron tablet and octahedral tablet, which is also called internal $\mathrm{O}-\mathrm{H}$ absorption peak. These four are characteristic absorption peaks of kaolinite [4]. Instead of the weak peak at $3669 \mathrm{~cm}^{-1}$, the shoulder peak of $3679 \mathrm{~cm}^{-1}$ was found in the spectrum, probably caused by the poor crystallization degree [5]. Peaks at 1112, 1030 and $1007 \mathrm{~cm}^{-1}$ are Si-O bond stretching vibration peaks, the absorption peak of $912 \mathrm{~cm}^{-1}$ is due to bending vibration of Al-O- $\mathrm{H}$ in octahedral sheet of Al-(OH.O). 794, 754, $696 \mathrm{~cm}^{-1}$, the absorption peaks of $\mathrm{Si}-\mathrm{O}, \mathrm{Si}-\mathrm{Si}$ and $\mathrm{Si}-\mathrm{Al}$ stretching vibration, were caused by quartz and feldspar which are associated with kaolin. Si-O bending vibration also generates peaks at 540, 470 and $430 \mathrm{~cm}^{-1}$. Therefore, kaolin is determined as the main component of the priming layer.

Kaolin, a natural hydrated silicate of aluminium, was widely used as white pigment in ancient wall paintings and painted sculptures in ancient China [6]. But using kaolin as priming layer is relatively rare. There was a thin kaolin layer beneath the paint layers in the Mogao Grottoes murals in Wei dynasty (220-266), Jin dynasty (266-420) and the Southern and Northern dynasty (420-589) [7]. It was also found in the priming layer of the clothes of a portrait in late Tang period (836-907), cave 10 [8]. Kaolin is not only produced in the vicinity of Jingdezhen, but also commonly found in other areas. The large use of kaolin as priming layer in the murals of the Five Northern Provinces' Assembly Hall is consistent with the geology of the region of Ziyang, where three 
Table 1 The paint layer tratigraphy and the pigments

\begin{tabular}{|c|c|c|c|c|c|}
\hline Colour & Sample & Layer (from top to bottom) & Thickness $(\mu \mathrm{m})$ & SEM-EDX & Pigments \\
\hline \multirow[t]{11}{*}{ Blue } & Gx-10 & Not continuous black layer & $2-3$ & $\mathrm{C}, \mathrm{O}$ & Flame carbons \\
\hline & & Dark blue layer & $11-30$ & $\mathrm{Cu}$ & Azurite \\
\hline & & Green layer & $11-20$ & $\mathrm{Cu}, \mathrm{Pb}$ & Malachite, lead white \\
\hline & $G x-15$ & White layer & $5-20$ & $\mathrm{~Pb}$ & Lead white \\
\hline & & Blue layer & $10-40$ & $\mathrm{Fe}$ & Prussian blue \\
\hline & Gd-3 & Not continuous blue layer & $5-10$ & $\mathrm{Fe}$ & Prussian blue \\
\hline & & Brown layer & $5-10$ & $\mathrm{~Pb}$ & Red lead, $\mathrm{PbO}_{2}$ \\
\hline & $Z \times 1-8$ & Blue layer & $40-70$ & $\mathrm{Si}, \mathrm{K}, \mathrm{Co}, \mathrm{As}, \mathrm{Fe}, \mathrm{Bi}, \mathrm{Ni}$ & Smalt \\
\hline & $Z \times 2-2$ & Not continuous blue layer & $8-20$ & $\mathrm{Fe}$ & Prussian blue \\
\hline & & Black layer & $2-3$ & $\mathrm{C}, \mathrm{O}$ & Flame carbons \\
\hline & Zb2-2 & Blue layer & $20-25$ & $\mathrm{Fe}$ & Prussian blue \\
\hline \multirow[t]{5}{*}{ Green } & Gx-9 & Green layer & $14-25$ & $\mathrm{Cu}, \mathrm{Pb}$ & Malachite, lead white \\
\hline & Gd-2 & Green layer & $11-25$ & $\mathrm{Cu}$ & Malachite, azurite \\
\hline & $Z \times 1-6$ & Green layer & $70-100$ & $\mathrm{Cu}, \mathrm{Cl}$ & Atacamite, botallackite \\
\hline & $Z \times 1-7$ & Green layer & $50-90$ & $\mathrm{Cu}, \mathrm{Pb}$ & Malachite, lead white \\
\hline & Zb 2-3 & Green layer & $20-28$ & $\mathrm{Cu}, \mathrm{Cl}, \mathrm{Pb}$ & Botallackite, lead white \\
\hline \multirow[t]{15}{*}{ Red } & $G x-11$ & Red layer & $10-28$ & $\mathrm{Hg}, \mathrm{S}, \mathrm{Pb}$ & Cinnabar, lead white \\
\hline & & Blue layer & $11-25$ & $\mathrm{Fe}$ & Prussian blue \\
\hline & Gx-14 & Dark red layer & $7-13$ & $\mathrm{Fe}, \mathrm{Ca}, \mathrm{K}, \mathrm{Al}, \mathrm{Si}$ & Red ochre \\
\hline & & White layer & $10-17$ & $\mathrm{~Pb}$ & Lead white \\
\hline & Gd-1 & Red layer & $7-15$ & $\mathrm{Hg}, \mathrm{S}, \mathrm{Pb}$ & Cinnabar, lead white \\
\hline & & Blue layer & $5-15$ & $\mathrm{Fe}$ & Prussian blue \\
\hline & $Z \times 1-5$ & Red layer & $20-40$ & $\mathrm{Hg}, \mathrm{S}$ & Cinnabar \\
\hline & $Z \times 1-14$ & Red layer & $5-8$ & $\mathrm{~Pb}, \mathrm{Fe}, \mathrm{Ca}, \mathrm{K}, \mathrm{Al}, \mathrm{Si}$ & Red ochre, lead white \\
\hline & & White layer & $5-10$ & $\mathrm{~Pb}$ & Lead white \\
\hline & $\mathrm{Zd}-3$ & Red layer & $2-4$ & $\mathrm{C}, \mathrm{O}, \mathrm{Al}, \mathrm{Si}, \mathrm{Ca}, \mathrm{Fe}$ & Dyestuff \\
\hline & & White layer & $3-4$ & $\mathrm{~Pb}$ & Lead white \\
\hline & $Z \times 2-3$ & Orange layer & $5-15$ & $\mathrm{~Pb}$ & Red lead \\
\hline & $Z \times 2-4$ & Orange layer & $12-20$ & $\mathrm{~Pb}$ & Red lead \\
\hline & $Z \times 2-5$ & Red layer & $14-22$ & $\mathrm{Hg}, \mathrm{S}$ & Cinnabar \\
\hline & & Orange layer & $12-25$ & $\mathrm{~Pb}$ & Red lead \\
\hline \multirow[t]{3}{*}{ Yellow } & Zx 1-13 & Yellow layer & $3-6$ & $\mathrm{Fe}, \mathrm{Ca}, \mathrm{S}, \mathrm{K}, \mathrm{Al}, \mathrm{Si}$ & Yellow ochre \\
\hline & & White layer & $8-12$ & $\mathrm{~Pb}$ & Lead white \\
\hline & Zb 2-4 & Yellow layer & $10-30$ & $A s, S$ & Orpiment \\
\hline \multirow[t]{3}{*}{ Brown } & Gx-7 & Brown layer & $5-8$ & $\mathrm{Fe}, \mathrm{Ca}, \mathrm{K}, \mathrm{Al}, \mathrm{Si}$ & Red ochre \\
\hline & Gx-8 & Brown layer & $5-20$ & $\mathrm{~Pb}, \mathrm{As}, \mathrm{S}$ & Red lead, lead white, $\mathrm{PbO}_{2}$, orpiment \\
\hline & $\mathrm{Gx}-12$ & Brown layer & $4-20$ & $\mathrm{~Pb}$ & Red lead \\
\hline White & $Z \times 1-12$ & White layer & $25-40$ & $\mathrm{~Pb}$ & Lead white \\
\hline Black & $Z \times 1-1$ & Black layer & $13-35$ & $\mathrm{C}, \mathrm{O}$ & Flame carbons \\
\hline \multirow[t]{3}{*}{ Gold } & $\mathrm{Zd}-2$ & Gold layer & $5-10$ & $\mathrm{Au}, \mathrm{Ag}, \mathrm{Cu}$ & Gold leaf \\
\hline & & Brownish red layer & $10-15$ & $\mathrm{C}, \mathrm{O}, \mathrm{Pb}$ & Red lead, binding media \\
\hline & & Thin layer with red particles & $2-3$ & $\mathrm{Hg}, \mathrm{S}$ & Cinnabar \\
\hline
\end{tabular}



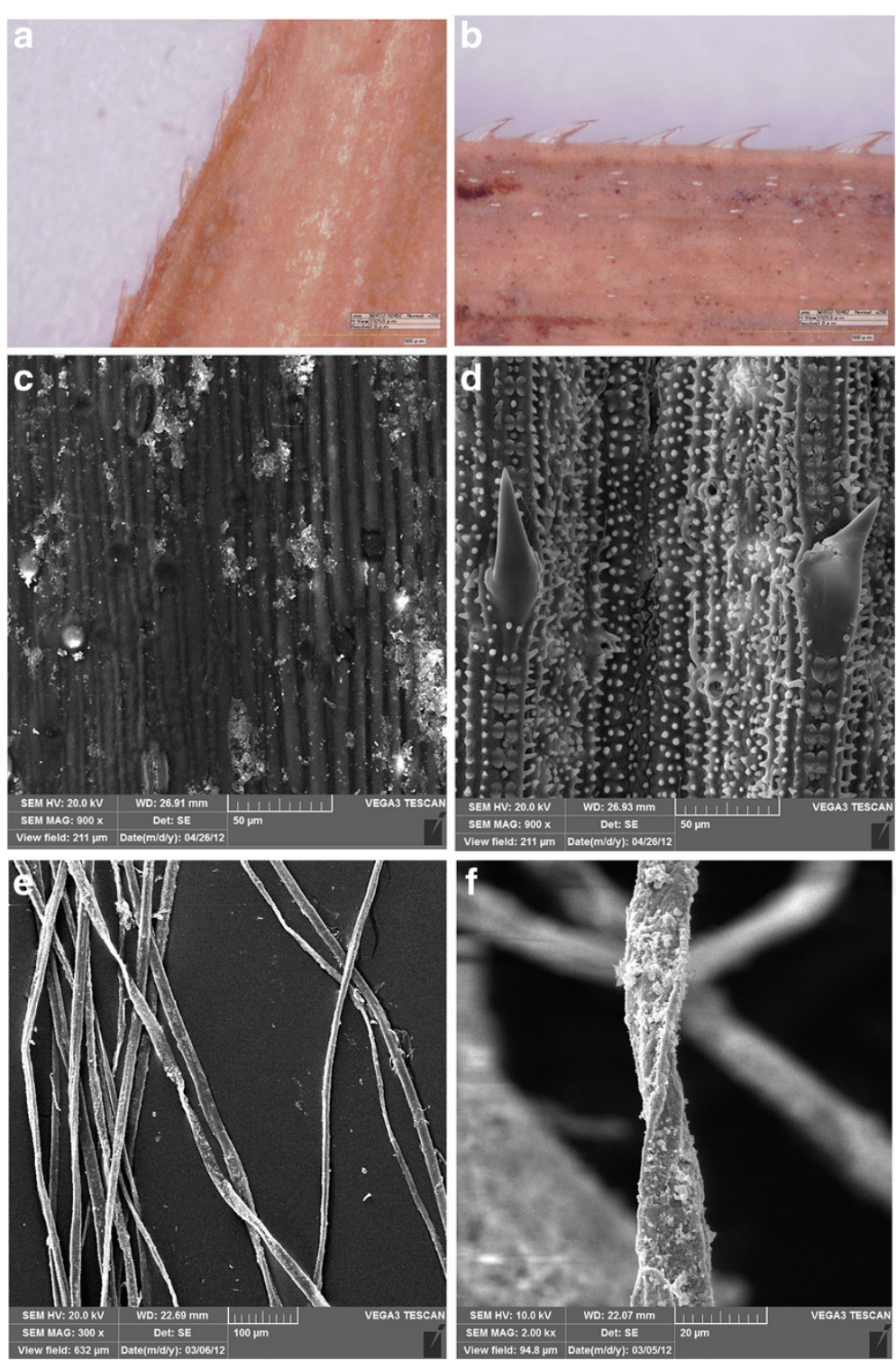

Figure 4 Micrographs of the fibres in plaster. Optical micrograph (a) and scanning electron micrograph (c) of rice straw in the coarse layer. Optical micrograph (b) and scanning electron micrograph (d) of fresh rice straw. Scanning electron micrographs (e,f) of cotton fibre from the fine layer.

kaolin ores (Jinchuan town, Qingjing town and Zihuang town) were recorded in Ziyang county annals.

\section{Painting layers \\ Blue pigments}

In dark greenish blue sample gx-10, three paint layers were observed from the cross-section (Figure 7a). The top one is a very thin and not continuous black layer, which is attached tightly to a dark blue layer. Blue particles of regular size (about $15 \mu \mathrm{m}$ ) and angular shape, with a high refractive index $(n>1.662)$ were found by PLM analysis, which suggests that the pigment is azurite. The micro-Raman characteristic peaks at 133, 179, 249,
283, 402, 765, 837, 1096, 1431, $1578 \mathrm{~cm}^{-1}$ also proved the presence of azurite.

The blue colourant existed in the transit hall and the main hall murals was not confirmed by PLM, and the blue particles of amorphous shape are characterized like a dyestuff or synthetic pigment, which needs further methods to determine (Figure $7 \mathrm{~b}$ ). The result of XRF shows the presence of $\mathrm{Ca}, \mathrm{Fe}, \mathrm{S}$ and $\mathrm{K}$. It is unreliable to characterize pigment with this method because many pigments contain iron. Moreover, the result could be influenced by plaster. In this case, the nature of this pigment could be completely determined by Raman spectroscopy. Figure 8a shows the micro-Raman spectrum of sample gx-15. It has peaks at 144, 277, 535, 2095, 

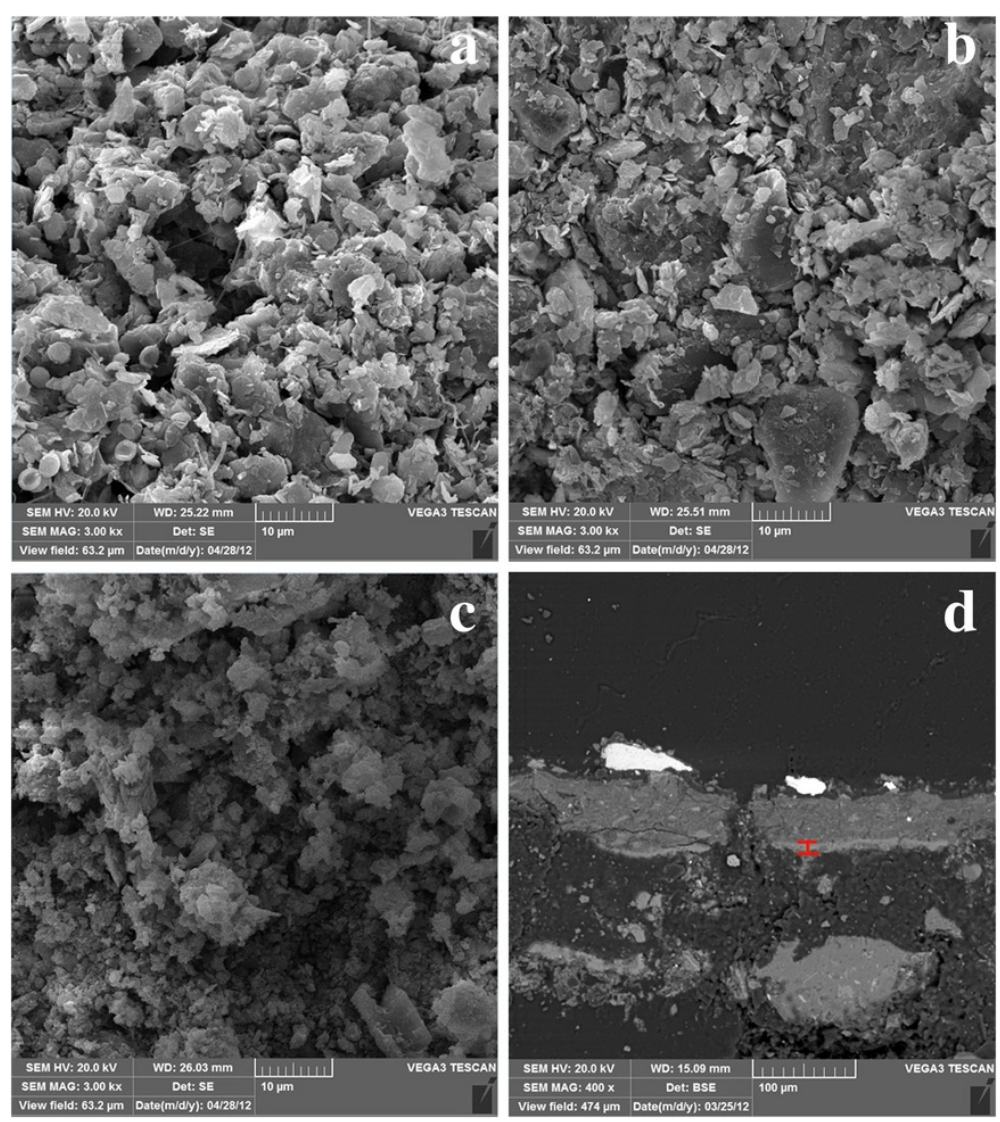

Figure 5 Scanning electronic micrographs of the plaster samples. Scanning electronic micrographs of the first coarse layer (a), the second coarse layer (b), the fine layer (c) and the cross-section of sample zx1-11 with a thin layer on the top of the fine coat (d).

$2154 \mathrm{~cm}^{-1}$, in accordance with the typical peaks of Prussian blue (282(vw), 538(vw), 2102(m), 2154(vs)) [9].

Prussian blue has been widely known as one of the earliest synthetic pigments and a complex chemical compound containing iron $\left(\mathrm{Fe}_{4}\left[\mathrm{Fe}(\mathrm{CN})_{6}\right]_{3}\right)$. It was prepared accidentally by Diesbach in 1704 in Berlin. It has been commercially available to artists by 1724 and widely used in paintings since the mid 18th century $[10,11]$. As a saturated radiant hue at a moderate cost, Prussian blue replaced the expensive natural ultramarine gradually. This pigment was widely identified on painted artifacts in Europe, East Asia and South America [12-14]. However, reports of Prussian blue used in ancient murals in China are limited. Therefore, the time of Prussian blue began to be imported to China and its applications need further research.

Another dark blue painted layer from an architecture part of the western mural in the main hall was thicker than others. Some larger pigment grains have been detached from the painting. It might be attributed to either mechanical friction of the wooden planks or aging of the binding medium. This blue sample was found as conchoidal glassy fragments in singly polarized fields with a low refractive index $(\mathrm{n}<1.662)$, suggesting a characterization of smalt (Figure 7c). Smalt is an artificial, glass-like potash silicate pigment, which is strongly coloured with cobalt oxide. Concerning smalt identification, besides the optical microscopy, the elemental micro-analysis by EDX is the best method. This blue sample contains several elements, including Si (58.0\%wt), Co (4.7\%wt), K (13.4\%wt), As (11.6\% $w t), \mathrm{Fe}(4.2 \% \mathrm{wt}), \mathrm{Bi}(4.5 \% \mathrm{wt})$ and $\mathrm{Ni}(1.5 \% \mathrm{wt}) . \mathrm{K}$ is the trace of the manufacturing process. Elements such as As and $\mathrm{Fe}$ indicate the origin of $\mathrm{CoO}$ from the mineral cobaltite $(\mathrm{Co}, \mathrm{Fe}) \mathrm{AsS}$, and $\mathrm{Ni}$ should come from the mineral smaltite $(\mathrm{Co}, \mathrm{Ni}) \mathrm{As}_{3-2}$. Bi exists in line with using the cobalt ore, which is coexisted with bismutite $\mathrm{Bi}_{2}\left(\mathrm{CO}_{3}\right) \mathrm{O}_{2}$, as an original material to produce smalt in Europe [15]. Furthermore, the Raman spectrum of sample zx 1-8 (Figure 8b) shows weak peaks (not sharp) at 461, 788, $1093 \mathrm{~cm}^{-1}$, which proved the presence of smalt.

The composition of smalt varies considerably in $\mathrm{SiO}_{2}$ (65-71, 66-72), $\mathrm{K}_{2} \mathrm{O}$ (16-21, 10-21), $\mathrm{CoO}(6-7,2-18)$ and in impurities of other oxides $(\mathrm{Al}, \mathrm{Ba}, \mathrm{Ca}, \mathrm{Cu}, \mathrm{Fe}$, $\mathrm{Mg}, \mathrm{Mn}, \mathrm{Ni}, \mathrm{Na}$ ) [16]. Ajò D. analyzed the painting materials of Ciro Ferri's frescoes in Italy and found that smalt contains $\mathrm{Si}(\sim 81.8 \%), \mathrm{Bi}(<1.0 \%), \mathrm{K}(\sim 7.1 \%), \mathrm{Ca}$ 
Table 2 EDX results of the plaster samples and the priming layer (wt \%)

\begin{tabular}{cccccccccccc}
\hline Samples & $\mathbf{C}$ & $\mathbf{O}$ & $\mathbf{N a}$ & $\mathbf{M g}$ & $\mathbf{A l}$ & $\mathbf{S i}$ & $\mathbf{S}$ & $\mathbf{K}$ & $\mathbf{C a}$ & $\mathbf{T i}$ & $\mathbf{F e}$ \\
\hline Gx-1 1st coarse layer & 3.27 & 31.73 & - & - & 12.78 & 38.62 & - & 2.39 & 0.66 & - & 10.54 \\
Zx 1-3 1st coarse layer & 4.04 & 37.40 & 0.63 & 1.07 & 10.02 & 36.50 & - & 2.40 & - & 1.47 & 6.48 \\
Gx-2 2nd coarse layer & 5.98 & 31.43 & - & 1.47 & 13.05 & 32.13 & - & 3.26 & 2.09 & 0.85 & 9.74 \\
Zx 1-2 2nd coarse layer & 3.79 & 34.29 & 0.49 & 1.53 & 12.45 & 33.85 & - & 3.37 & - & 0.89 & 9.36 \\
Zb 3-2 2nd coarse layer & 2.92 & 31.26 & 1.26 & 1.73 & 11.94 & 30.71 & 2.99 & 3.08 & 3.80 & - & 10.30 \\
$\quad$ Gx-3 fine layer & 7.68 & 41.27 & - & 1.07 & 4.00 & 9.01 & 1.13 & 0.97 & 32.06 & - & 2.83 \\
Zx 1-1 fine layer & 7.41 & 40.48 & 0.41 & 1.34 & 4.42 & 12.37 & - & 1.17 & 29.04 & - & 3.35 \\
Zb 3-2 fine layer & 6.08 & 35.88 & 0.80 & 1.68 & 6.15 & 14.05 & 1.30 & 1.03 & 27.96 & - & 5.07 \\
Zx 1-9 surface of fine layer & 10.33 & 37.49 & - & 0.65 & 1.78 & 3.93 & 2.52 & - & 42.13 & - & 1.18 \\
Zx 2-5 surface of fine layer & 9.30 & 37.25 & 0.40 & 0.57 & 1.92 & 5.87 & 0.82 & 0.63 & 42.13 & - & 1.11 \\
\hline
\end{tabular}

$(\sim 2.6 \%)$, Fe $(\sim 1.9 \%)$, Co $(\sim 3.3 \%)$, Ni $(<1.0 \%)$ and As $(\sim 2.2 \%)$ by SEM-EDX [17]. Daniilia S. found two kinds of smalt in St Stephen's wall paintings at Meteora, Greece, the EDX results show the following mean composition: (a) Si (68.9\%), K (22.6\%), Co (4.1\%), Ca (2.2\%) and $\mathrm{Fe}(2.5 \%)$; (b) $\mathrm{Si}(85.4 \%), \mathrm{K}(3.9 \%)$, Co (3.3\%), Ca (1.1\%), Fe (2.1\%), Al (1.6\%) and As (2.7\%) [16]. Compared with these results, smalt used in the Five Northern Provinces' Assembly Hall contains much more As, which suggests that the original mineral is rich in As.

The earliest invention of smalt was in Saxony and its surrounding areas in Germany. Smalt was formed by the following steps: Firstly, cobalt ore was fused and mixed with white quartz after grinding and baking, then potassium carbonate or other cosolvents were added, the molten material was poured into cold water to form brittle glass in the end. Evidence of smalt used as pigment dates from the 15 th to early 19 th century. In the early 17 th century, it is mentioned that smalt has been widely used in oil painting and substituted lapis lazuli and azurite as they became more and more scarce $[15,18]$. While in ancient China, the pigment was usually used in architecture coloured drawing of the Qing dynasty, for instance, JianFu palace in the Forbidden City, Xiannongtan in Beijing, Shuxiang Temple in Chengde and some other sites [16]. Since smalt has been produced in Germany and Italy at that time, it is uncertain to determine the source of smalt used in murals of the Five Northern Provinces' Assembly Hall until more analytical data collected.

\section{Green pigments}

Sample gx-9, gd-2 and zx1-7 have a single green layer with a large amount of $\mathrm{Cu}$. Some green angular shaped particles with a high refractive index $(n>1.662)$ are correspond to malachite. It has been further confirmed by XRD. Similarly, malachite was found in the third green layer of sample gx-10.

The PLM photomicrograph of sample zx1-6 (Figure 7d) shows green particles of uniform size $(10-20 \mu \mathrm{m})$ and round shape, with a low refractive index $(\mathrm{n}<1.662)$, which are as same as atacamite. Furthermore, the presence of atacamite has been proved by EDX (40\%at $\mathrm{Cu}$ and $21 \%$ at $\mathrm{Cl})$ and $\mu-\mathrm{RS}$.

Copper-based green pigments were identified in samples, malachite and atacamite, are the principal green pigments widely found in ancient wall paintings [19-21]. They were used to depict trees, grasses, garments of the figure and the panel framings of the Chinese folding screens in the Five Northern Provinces' Assembly Hall murals. The colours range from light green to dark green. Malachite was widely used in every mural, while

Table 3 XRD results of the plaster samples (wt \%)

\begin{tabular}{|c|c|c|c|c|c|c|c|c|c|}
\hline Samples & Quartz & Plagioclase & K-feldspar & Calcite & Gypsum & Montmorillonite & Illite & Chlorite & Kaolinite \\
\hline Zx 1-3 1st coarse layer & 73.3 & 9.0 & 4.3 & - & 1.4 & - & 6.0 & 2.0 & 4.0 \\
\hline Gx-2 2nd coarse layer & 75.2 & 6.6 & 3.8 & 0.4 & - & 2.0 & 9.0 & - & 3.0 \\
\hline Zx 1-2 2nd coarse layer & 74.6 & 9.9 & 2.6 & - & 0.9 & - & 9.0 & - & 3.0 \\
\hline Zb 3-2 2nd coarse layer & 73.0 & 9.6 & 1.2 & 5.9 & 3.3 & - & 4.0 & - & 3.0 \\
\hline Zx 1-1 fine layer & 52.7 & 3.7 & - & 31.0 & 5.6 & - & 7.0 & - & - \\
\hline Zx 1-9 fine layer & 65.0 & 7.3 & - & 10.4 & 3.3 & - & 7.0 & - & 7.0 \\
\hline Gx-3 fine layer & 52.8 & 6.0 & 1.8 & 21.9 & 0.5 & - & 9.0 & 3.0 & 5.0 \\
\hline Zb 3-2 fine layer & 57.3 & 6.2 & 1.0 & 24.2 & 0.3 & 1.0 & 7.0 & - & 3.0 \\
\hline
\end{tabular}




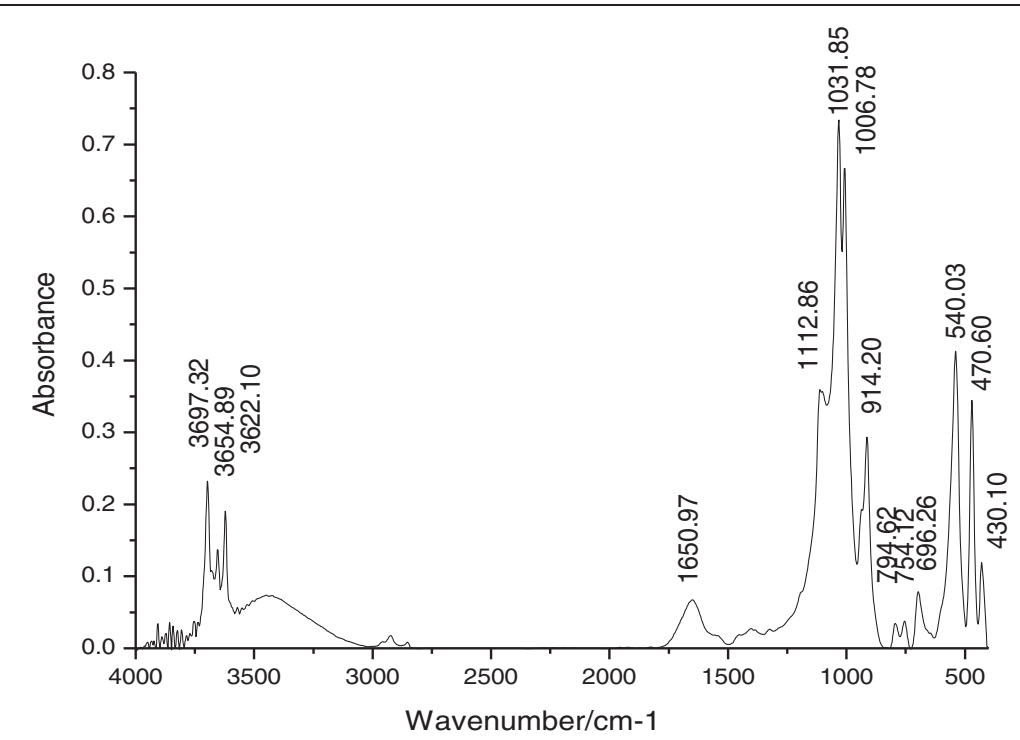

Figure 6 IR absorption spectrum of the priming layer of sample $\mathbf{z x} 1-8.3697,3679,3654 \mathrm{~cm}^{-1}-\mathrm{v}(\mathrm{O}-\mathrm{H}) ; 3620 \mathrm{~cm}^{-1}-\mathrm{v}(\mathrm{O}-\mathrm{H}) ; 1112,1030,1007$ $\mathrm{cm}^{-1}$ - v(Si-O); $912 \mathrm{~cm}^{-1}-\delta(\mathrm{Al}-\mathrm{O}-\mathrm{H}) ; 794,754,696 \mathrm{~cm}^{-1}-\mathrm{v}(\mathrm{Si}-\mathrm{O}), \mathrm{v}(\mathrm{Si}-\mathrm{Si})$ and $\mathrm{v}(\mathrm{Si}-\mathrm{Al}) ; 540,470,430 \mathrm{~cm}^{-1}-\delta(\mathrm{Si}-\mathrm{O})$.

atacamite-pigmented layers were thick and just for the decoration of the figures and horses in the main hall murals.

Sample zb2-3 from the northern wall of the main hall contains $\mathrm{Cu}$ and $\mathrm{Cl}$ was not determined by PLM analysis. Green rounded particles combined with lead white, similar to lead white, but with a lower index of refraction were observed in PLM photomicrograph. Figure $8 \mathrm{c}$ shows the Raman spectrum of sample zb2-3. Peaks at $153,175,250,278,401,446,512,778,850,895$, $1049 \mathrm{~cm}^{-1}$ are well matched with the standard botallackite $(155(\mathrm{~m}), 175(\mathrm{~m}), 251(\mathrm{~m}), 279(\mathrm{~m}), 324(\mathrm{w})$, 401(vs), 450(vs), 503(w), 678(w), 857(m), 897(m)) and lead white $(1050(\mathrm{vs}))$ in database. It was also proved successfully by XRD analysis.

Botallackite, one structural polymorph of atacamite, is a rare green pigment due to its lower stability. It has been found on the painted sculptures at Dunhuang Grottoes and Houtu Temple located in Jiexiu, Shanxi Province, as well as on the wall painting of the Fuxi Temple in Gansu Province [22]. While on the murals of the Five Northern Provinces' Assembly Hall, botallackite was not only found in the green sample of zb2-3 as main compound, but also in mixtures with atacamite or malachite. Botallackite is the most unstable phase in all copper trihydroxychloride, which suggests that it might change to atacamite. Unfortunately, study on botallackite is much less than other green pigments. The formation and development between structural polymorphs of copper trihydroxychloride, and the source, application and protection of botallackite need to be further explored.

\section{Red and brown pigments}

In sample zx1-14, two paint layers were observed. A thin white layer was covered by a pink layer formed by red and white particles. The red pigment is very fine and looked red with a high refractive index $(n>$ 1.662). Chemical analysis performed on the pink layer of zx1-14 cross-section indicates the presence of Fe, $\mathrm{Pb}, \mathrm{Ca}, \mathrm{Si}, \mathrm{Al}, \mathrm{K}, \mathrm{C}$ and $\mathrm{O}$, which suggests red ochre and lead white. As well sample gx-14 was also proved as red ochre based on the identification of $\mathrm{Si}, \mathrm{Al}$ and other elements from clays. Red and yellow iron-based pigments are the earliest and indispensable painting materials for ancient painters. It is reported that earthy pigments containing iron oxides and hematite were found to be used in the murals in every dynasty of ancient China [23].

It is known that red lead and cinnabar are considered as the commonest pigments of ancient China [23,24]. These two kinds of red pigments were also extensively used in the murals of the Five Northern Provinces' Assembly Hall.

The XRD pattern of sample $\mathrm{gx}-8$ is with peaks at 26.38, 30.78, 28.53, indicating the presence of $\mathrm{Pb}_{3} \mathrm{O}_{4}$ and $\mathrm{PbO}_{2}$. A brown layer on top and some red particles underneath were shown in the cross-section micrograph (Figure 7e), which reveals that the brown layer is $\mathrm{PbO}_{2}$, an aging product of red lead [25]. Besides, a few yellow particles contain As and S were observed on the surface of the sample, which suggests that orpiment was mixed with red lead. And pinkish brown hue of the sample was caused by partial aging of red lead. 

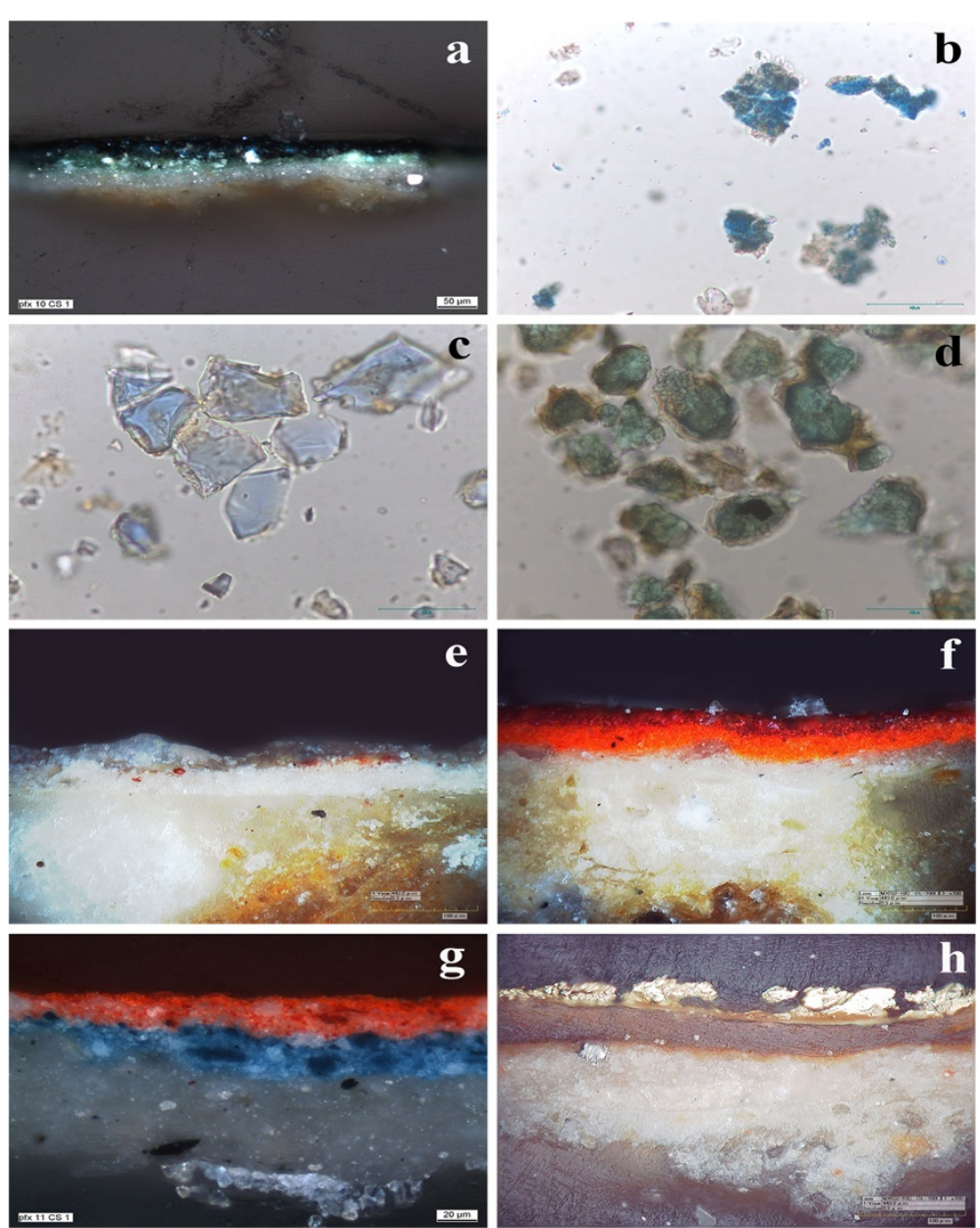

Figure 7 PLM and cross-section photomicrographs of the samples. The cross-section photomicrographs of sample gx-10 ${ }^{\mathrm{a}}$ (a): (1) thin and uncontinuous black layer, (2) dark blue layer, (3) green layer; sample gx-8 (e): (1) brown layer, (2) red layer; sample zx2-5 (f): (1) red layer, (2) orange layer; sample gx-11 (g): (1) red layer, (2) blue layer; sample zd-2 (h): (1) gold leaf, (2) brownish red binding media layer, (3) red particles. PLM photomicrographs of sample gx-15 (b) showing the blue pigment of Prussian blue, sample zx1-8 (c) showing the blue pigment of smalt and sample zx1-6 (d) showing the green one of atacamite.

Sample zx2-5, 2-4 and 2-3 were collected from the western wall painting in the main hall depicted with a pearl in the clouds, which is dark red in centre and surrounded by orange cycles. The PLM photomicrographs of sample zx2-3 and zx2-4 show the characteristics of red lead. Sample zx2-5 was taken from the dark red centre and with two paint layers (Figure 7f). An orange layer was covered by a red surface. Amounts of $\mathrm{Hg}$ (35\%at) and S (36\%at) in the upper layer reveal that the red pigment is cinnabar. And the lower one is from the next external orange cycle paint layer and painted with red lead (74\%wt $\mathrm{Pb})$. The results suggest that cinnabar was applied directly over the red lead layer. In addition, sample gx-11 and gd-1 have a red layer on top of a blue layer (Figure $7 \mathrm{~g}$ ). These samples were collected from the frame of the traditional Chinese folding screens depicted on the transit hall wall, which is decorated with a colourful pattern of red blossoms or stars on bright blue background. The presence of cinnabar and lead white in the upper layer are detected from the data of $26.0 \%$ wt $\mathrm{Hg}, 8.3 \%$ wt $\mathrm{S}$ and $48.8 \% \mathrm{wt} \mathrm{Pb}$. The lower one is pigmented with Prussian blue, which was identified by PLM. The results indicate that the blue colour was painted in the frame first and then the red flowers were depicted on it. In conclusion, two paint layers of the samples formed by the painting sequence.

Furthermore, another red colourant was found in the main hall mural. The cross-section examination of sample $\mathrm{zd}-3$ shows a thin translucent pink paint layer is painted above a thicker white under-painting. A large amount of $\mathrm{Pb}(64 \% \mathrm{wt})$ reveals that the white layer was pigmented by lead white. The pink layer was characterized as a reddish pink lake or dyestuff by PLM analysis. In addition, a large amount of $\mathrm{C}$ (more than $41 \% \mathrm{wt}$ ) and a relatively higher amount of $\mathrm{Al}$ also suggests that the red colourant is an organic dyestuff. It is well-known 

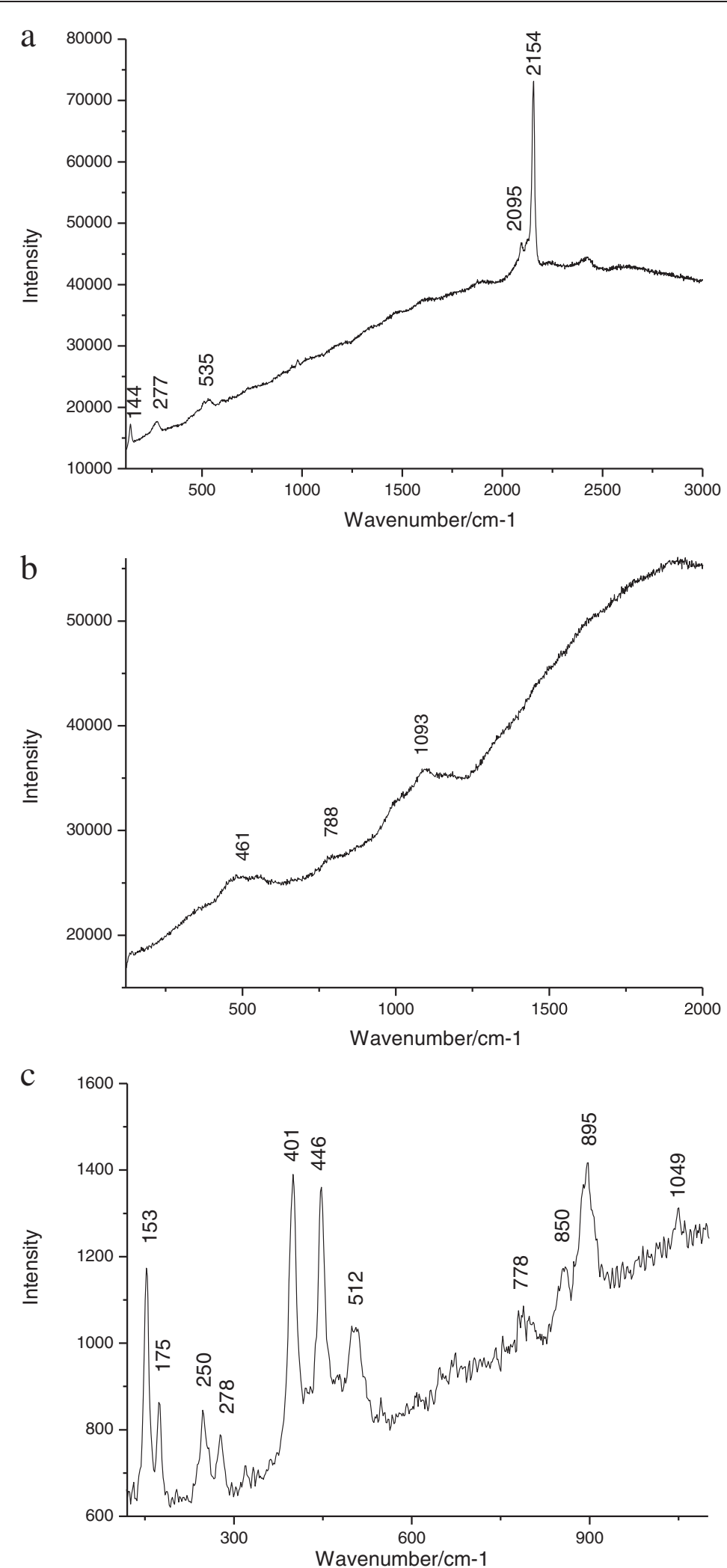

Figure 8 Raman spectrums of the samples. Raman spectrum of sample gx-15 (a): $2095 \mathrm{~cm}^{-1}(\mathrm{~s})-\mathrm{vas}(\mathrm{C}-\mathrm{N}), 2154 \mathrm{~cm}^{-1}(\mathrm{vs})-\mathrm{vs}(\mathrm{C}-\mathrm{N})$; sample zx18 (b): $461 \mathrm{~cm}^{-1}(\mathrm{w}), 788 \mathrm{~cm}^{-1}$ (w) - $\delta(\mathrm{Si}-\mathrm{O}), 1093 \mathrm{~cm}^{-1}$ (w) - v(Si-O); sample zb2-3 (c): $153 \mathrm{~cm}-1(\mathrm{~m})-\gamma \mathrm{s}(\mathrm{Cl}-\mathrm{Cu}-\mathrm{Cl}), 175 \mathrm{~cm}{ }^{-1}(\mathrm{~m})-\gamma(\mathrm{O}-\mathrm{Cu}), 250 \mathrm{~cm}-$ $1(\mathrm{~m}), 278 \mathrm{~cm}-1(\mathrm{~m})-\delta(\mathrm{O}-\mathrm{Cu}-\mathrm{O}), 401 \mathrm{~cm}-1(\mathrm{vs}), 446 \mathrm{~cm}-1(\mathrm{vs}), 512 \mathrm{~cm}-1$ (vs) - vs(O-Cu-O), $778 \mathrm{~cm}-1(\mathrm{w}), 850 \mathrm{~cm}-1(\mathrm{~m}), 895 \mathrm{~cm}-1(\mathrm{~m})-\delta(\mathrm{Cu}-\mathrm{O}-\mathrm{H})$. 
that dyestuff is usually added with alum or other inorganic substrates such as chalk, silica or gypsum. It is possible to use organic lake to produce pink hue because it began to be imported during the Qing dynasty.

In summary, most of the red and brown colourants are pigments as red ochre, red lead and cinnabar, only one sample from the main hall contains dyestuff or a lake. Bright red areas were painted with cinnabar and orange ones were red lead.

\section{Yellow pigments}

Yellow was used less in the murals than other colours. Bright yellow was identified as orpiment. It was used to paint the panel framings of the Chinese folding screens. In sample zb2-4, 23\%at As and 34\%at S show that the pigment is orpiment. Orpiment was found either with a large amount on the northern mural in the main hall or few particles mixed with red lead in the pinkish brown framing of the western transit hall mural.

There is another yellow pigment in a light ochre yellow colour was used to depict the cloth hanging from the table or the hanging flag in the western main hall mural. Pigment particles in sample zx1-13 are very fine and looked yellowish red with a high refractive index $(n>1.662)$, combined with the content of $\mathrm{Fe}, \mathrm{Ca}, \mathrm{S}, \mathrm{Si}$, $\mathrm{Al}$ and $\mathrm{K}$ proves the presence of yellow ochre.

\section{White pigments}

White pigment was found from a single white paint layer, an under-painting or a coloured paint layer mixed with other pigments from the cross-sections examination. In sample zx1-12, zd-3 (red) and zx1-13 (yellow), a large amount of $\mathrm{Pb}$ in the white layer reveals it is lead white. On the other hand, the presence of very fine white particles in many samples with a high refractive index was also proved as lead white by PLM analysis.

The use of lead white as white pigment has been increased gradually since the Qin and Han dynasty (211 B. C-8) [26]. Furthermore, it was more common in Shaanxi Province [27]. Lead white used in the murals of the Five Northern Provinces' Assembly Hall either as the major constituent or mixed with other coloured pigments to produce different hues.

\section{Black pigments}

Black was found on the frame of painting or as contour lines of the depictions. Three samples with black colour were collected. These black particles are very fine and with a high refractive index $(n>1.662)$, combined with the content of $\mathrm{C}, \mathrm{O}$ suggests the presence of flame carbons.

\section{Gold}

Three paint layers were observed from the cross-section of zd-2 (Figure 7h). There is a brownish red layer between a gold leaf and some red particles. The gold layer was found to be dominated by $\mathrm{Au}$ (89.3\%wt) with less amounts of $\mathrm{Ag}(8.5 \% \mathrm{wt})$ and $\mathrm{Cu}(2.2 \% \mathrm{wt})$, which could be explained reasonably as elements $\mathrm{Au}, \mathrm{Ag}$ and $\mathrm{Cu}$ belong to the same subgroup may naturally symbiosis. The below brownish red layer with a large amount of $\mathrm{C}$ and less amount of $\mathrm{Pb}$ gives the evidence that it is the binding media to attach gold leaf. Meanwhile, the presence of $\mathrm{Hg}(8.1 \%$ at $)$ and $\mathrm{S}(7.7 \%$ at $)$ suggests that the red particles are cinnabar.

Qing Chen has found red lead and $\mathrm{PbO}_{2}$ in gold leaf samples from the mural of the Second Grotto of Eastern Thousand-Buddha Cave in Gansu Province and the Longzang Temple in Sichuan [28]. The adhesive material on the One-thousand-hand Buddha at Dazu Grotto was a mixture of $\mathrm{HgS}$, tong oil and lacquer [29]. Yong Lei found a layer of binding media within red iron oxide was under the gold leaf of the murals in the Temples under Chieftain Lu in Liancheng, Gansu Province [30]. In conclusion, cinnabar, red lead or other red pigments were commonly added into the gilding adhesive aims to enhance the colour of gold [31]. Therefore, the presence of $\mathrm{HgS}$ and $\mathrm{Pb}_{3} \mathrm{O}_{4}$ in the adhesive material of the gold leaf samples from the assembly hall mural was proved following the traditional way.

\section{Conclusions}

8 plaster and 28 paint layer samples were investigated by various analytical methods, including polarized light microscopy, microscopic examination on cross-sections, $\mathrm{x}$-ray fluorescence, $\mathrm{x}$-ray diffraction, micro-Raman spectroscopy, Fourier transform infrared spectroscopy and SEM-EDX to examine the stratigraphy of the mural and identify the materials used.

The entire stratigraphy of the mural in the Five Northern Provinces' Assembly Hall from bottom to top is divided into 6 parts: brick wall - the first coarse layer $(10-12 \mathrm{~mm})$ the second coarse layer $(5-7 \mathrm{~mm})$ - fine layer $(3-5 \mathrm{~mm})$ priming layer $(20-60 \mu \mathrm{m})$ - paint layer $(5-40 \mu \mathrm{m})$. In addition, it is assumed that the murals have not been restored and the materials are original by the examination in site and investigation of the cross-sections. Some samples have several painting layers as a result of the painting sequence.

The main ingredients of the plaster are quartz, calcite, illite and plagioclase. The coarse layer is a mixture of clay, sand and rice straw, while the fine coat consists of lime, clay, sand and cotton. Recipes of the plaster in the transit hall and main hall are basically the same. The priming layer was identified as kaolin which is relatively rare. However, it is smooth, high whiteness and in line 
with the principle of using local materials for ancient murals. Three kaolin ores in Ziyang are all along the rivers, which also proves the developed shipping and commerce of Wafangdian in the middle of the Qing dynasty.

Table 1 shows the results of the pigments used for the wall paintings in the Five Northern Provinces' Assembly Hall. Only one red dyestuff was found, other colourants are all inorganic. Red lead, red ochre, cinnabar, atacamite, malachite, botallackite, orpiment, yellow ochre, Prussian blue, smalt, azurite, lead white, flame carbons were used. Pigments like smalt, atacamite were found only in the main hall murals, others were used in all murals. The usage of the imported pigments Prussian blue and smalt proves the geographic position of the Five Northern Provinces' Assembly Hall was of crucial importance for trade. Meanwhile, the selective application of smalt is in accordance with the high value of the paintings and the important position of the main hall. Lead white was widely used, both as a pigment by itself or as a whitening agent mixed with other pigments. In addition, Prussian blue and botallackite as main components of pigments used in ancient murals in China was not widely reported, so research on the source, application and protection should be carried on. The rest of the pigments identified on the examined samples, represent the common painting materials in China.

The development of the technique of Chinese ancient murals is divided into several stages. It is well-known that China was in a political and economic boom in the Tang dynasty (618-907), and the technique of murals had reached its peak. Then a comprehensive technique of the ancient temple mural was formed in the Song dynasty (960-1279). From the Ming dynasty (13681644), the quality of the murals was on the decline. As a result of the development of the literati paintings in the Qing dynasty, murals were designed and drawn by the organization of folk painters, which was without unified management and standard, the technique was simplified in general. However, the investigation indicates that the murals of the Five Northern Provinces' Assembly Hall are of high quality and the techniques followed the traditional and standard way.

\section{Endnote}

${ }^{a}$ Figure $7 \mathrm{a}$ and $\mathrm{g}$ are from German analyses report of the murals of The Five Provinces' Assembly Hall.

\section{Competing interest}

All authors declare that they have no competing interest.

\section{Authors' contributions}

$\mathrm{DBL}, \mathrm{BBF}$ and LYM have participated in samples preparation. $\mathrm{KJH}$ has performed the analyses and drafted the manuscript. LYM and KB have helped to draft the manuscript. CBB has been involved in the statistical interpretation and revising the manuscript critically for important intellectual content. All authors read and approved the final manuscript.

\section{Authors' information}

$\mathrm{KJH}$ Graduate student for a Master's degree, major in Conservation of Cultural Heritage, School of Cultural Heritage, Northwest University, Xi'an (Shaanxi), P.R. China.

CBB Professor and researcher, Shaanxi Province Institute for the Conservation and Restoration of Cultural Heritage, Xi'an, P.R. China. Graduated from Northwest University.

LYM Associate research fellow, Shaanxi Province Institute for the Conservation and Restoration of Cultural Heritage, Xi'an, P.R. China. Graduated from Xi'an Academy of Fine Arts.

KB Research Assistant, Shaanxi Province Institute for the Conservation and Restoration of Cultural Heritage, Xi'an, P.R. China. Graduated from Beijing University.

DBL Research Assistant, Shaanxi Province Institute for the Conservation and Restoration of Cultural Heritage, Xi'an, P.R. China. Graduated from Xi'an Academy of Fine Arts.

BBF Associate research fellow, Shaanxi Province Institute for the Conservation and Restoration of Cultural Heritage, Xi'an, P.R. China.

\section{Acknowledgements}

This work is a part of a German-Chinese cooperation in the preservation of Cultural Heritage. We would like to thank Technical University of Munich Prof. Erwin Emmerling, Catharina Blaensdorf, Miriam Schanz, Isabell Wagner, Linda Zachmann and Laura Thiemann for their assistance and support. And thank Yin Xia (Key Scientific Research Base of Ancient Polychrome Pottery Conservation, State Administration for Cultural Heritage) for his assistance in the PLM analyses. We also want to show our gratitude to Prof. Liqin Wang, Prof. Cheng Liu, Dr. Rui Wen, Dr. Yong Ling, Prof. Xue Ling in Laboratory of Cultural Heritage Research and Protection in Northwest University.

Received: 18 March 2013 Accepted: 28 May 2013

Published: 3 June 2013

\section{References}

1. Li S: Art overview of the mural in Baiyun temple in Jia County, Shaanxi Province. Chinese Calligraphy and Painting 2008, 7:16-21.

2. Wang CB: Qing dynasty mural in Houzhou Queen wa temple. World of Antiquity 2011, 1:75-77.

3. Chinese Textile Identification and Protection Centre: Survey on identification and protection of textile. Beijing: Cultural Relics Press; 2002.

4. Zhou LD, Guo JG, Yang NH, et al: Petrology and petrochemistry of alkalirich intrusions, China. Chinese J Sci D 1996, 6:561.

5. $\mathrm{Li} \mathrm{XH}$, Jiang XP, Chen $\mathrm{C}$, et al: Research on diffuse relectance infrared fourier transform spectroscopy of kinds of kaolin in various areas. Spectroscopy and Spectral Analysis 2011, 31:114-118.

6. Li ZX: Pigment analysis on Tang dynasty murals at the Mogao Grottes. Dunhuang Res 2002, 4:11-18.

7. Hou XB: Study on changes and developments of Chinese ancient murals from the view of materials and techniques. Relics and Museology 2011, 4:58-64.

8. Duan XY, Li J, Li TZ: Pigment analysis and discussion on cave 232, 35 mural the Mogao Grottes. Dunhuang Res 1991, 3:96-106.

9. Bell IM, Clark RJH, Gibbs PJ: Raman spectroscopic library of natural and synthetic pigments (Pre-1850 AD). Spectrochimica Acta Part A 1997, 53:2159-2179

10. von Aderkas EL, Barsan MM, Gilson DFR, et al: Application of photoacoustic infrared spectroscopy in the forensic analysis of artists' inorganic pigments. Spectrochim Acta A Mol Biomol Spectrosc 2010, 77:954-959.

11. Daniilia S, Minopoulou E, Andrikopoulos KS, et al: Evaluating a Cumaean Sibyl: Domenichino or later? A multi-analytical approach. Analytica Chinaca Acta 2008, 2:239-249.

12. Kovala-Demertzi D, Papathanasis L, Mazzeo R, et al: Pigment identification in a Greek icon by optical microscopy and infrared microspectroscopy. J Cultural Heritage 2012, 13:107-113.

13. Manso M, Valadas S, Pessanha S, et al: Characterization of Japanese colour sticks by energy dispersive $\mathrm{X}$-ray fluorescence, $\mathrm{X}$-ray diffraction and Fourier transform infrared analysis. Spectrochimica Acta Part B 2010, 65:321-327.

14. Calza C, Pereira MO, Pedreira A: Characterization of Brazilian artists' palette from the XIX century using EDXRF portable system. Appl Radiat Isot 2010, 68:866-870. 
15. Lei $Y$, Cheng $X L$, Yang H: Study of Smalt in the architectural paintings in Jian Fu Gong of the Imperial Palace. J Imperial Palace 2010, 4:140-156.

16. Danilia S, Minopoulou E, Andrikopoulos KS, et al: From Byzantine to postByzantine art: the painting technique of St Stephen's wall paintings at Meteora, Greece. J Archaeol Sci 2008, 35:2474-2485.

17. Ajò $D$, Casellato U, Fiorin $E$, et al: Ciro Ferri's frescoes: a study of painting materials and technique by SEM-EDS microscopy, X-ray diffraction, micro FT-IR and photoluminescence spectroscopy. I Cultural Heritage 2004, 5:333-348.

18. Danilia S, Minopoulou E, Demosthenous D: A comparative study of wall paintings at the Cypriot monastery of Christ Antiphonitis: one artist or two. J Archaeol Sci 2008, 35:1695-1707.

19. Wang JY, Wang JC: Application and source of copper-based green pigments in Dunhuang grottoes. Dunhuang Res 2002, 4:23-27.

20. Su BM, Li ZX, Ma ZF, et al: Study on the mural pigments of Kizil grottoes. Dunhuang Res 2000, 1:65-75.

21. Xia Y, Guo H, Wang JH, et al: A study of the mural pigments of A-er-zhai Grottoes, Inner Mongolia. Sci Conserv Archaeology 2007, 19:41-46.

22. Xia Y, Wang WF, Liu LX, et al: Study on mural painting pigments of Fuxi Temple, Tianshui, Gansu Province. Sci Conserv Archaeology 2011, 23:18-24.

23. Zhou GX, Cheng HW: Ancient pigments in China. Paint and coatings Industry 1991, 1:30-36.

24. Zhou GX: Cinnabar in China and Its development in function. Dunhuang Res 2010, 2:51-59.

25. Gong MT, Xin XH, Han F, et al: Study on Discolouration of red lead. Relics and Museology 2009, 6:479-486.

26. Li YF, Zhao LY, Wang XD: Primary studies on the materials and technology of the painted sculptures from Houtu Temple in Shanxi Province. Relics and Museology 2009, 6:118-124.

27. Lu LY: Pigment analysis and conservation of Tang dynasty coloured pottery figurines at the Shenzhen Museum. Sci Conserv Archaeology 2011, 23:64-70.

28. Chen Q, Wei Q: Study on the mural pigments in Longzang Temple in Xindu. Sichuan Cultural Relics 2004, 6:87-90.

29. Hu DB, Xue YN, Wang JH, et al: An analytical study of gilding and adhesive materials on the One-thousand-hand Buddha at Dazu Grotto, Baoding Mountain, Chongqing. Sci Conserv Archaeology 2008, 20:44-51.

30. Lei $Y$, Wen $M, C$ Cheng $X L$ : An investigation of the murals preserved in the temples under Chieftain Lu in Liancheng, Yongdeng County, Gansu Province. J Imperial Palace 2012, 2:133-154.

31. He HL, Tao SZ: Science of Lacquer Decoration. Fujian: Fujian Art Press; 1990.

\section{doi:10.1186/2050-7445-1-18}

Cite this article as: Hu et al:: A study on the painting techniques and materials of the murals in the Five Northern Provinces' Assembly Hall, Ziyang, China. Heritage Science 2013 1:18.

Publish with ChemistryCentral and every
scientist can read your work free of charge
"Open access provides opportunities to our
colleagues in other parts of the globe, by allowing
anyone to view the content free of charge."
W. Jeffery Hurst, The Hershey Company.
- available free of charge to the entire scientific community
- peer reviewed and published immediately upon acceptance
- cited in PubMed and archived on PubMed Central
- yours - you keep the copyright
Submit your manuscript here:
http://www.chemistrycentral.com/manuscript/

